\title{
A MANOEUVRE WARFARE ANALYSIS OF SOUTH AFRICA'S 1914-1915 GERMAN SOUTH WEST AFRICAN CAMPAIGN
}

\author{
Antonio Garcia \\ New York University ${ }^{1}$
}

\begin{abstract}
The study reported in this article explored the nexus between military theory and history. Military theory attempts to quantify, qualify and illuminate the often unpredictable phenomenon of war. The article consists of two parts: the theory of manoeuvre warfare and the history of the 1914-1915 South African campaign in German South West Africa (GSWA). The GSWA campaign has been described in many ways as a secondary theatre within the greater geostrategic chess game of the First World War. The objective of this analysis was to question whether the South African victory resulted from vast numerical superiority or from the operational concepts, which the South Africans applied in the execution of the campaign.
\end{abstract}

\section{Introduction}

At the outbreak of the First World War, the then Union of South Africa found itself in an uncertain political situation. The Union was formed in 1910 and was still in the process of reconciliation following the South African War (1899-1902). There was strong anti-British sentiment within the Union with a large number of Afrikaners wanting complete independence from the Crown.

The 1914-1915 campaign in GSWA was an integral part of the British international strategy during the Great War (1914-1918). South Africa found itself fighting on the side of the British despite still nursing wounds of the South African War. The leadership of Louis Botha (prime minister) and Jan Smuts (Minister of Defence) motivated the invasion of GSWA as necessary in the defence of the Union

Scientia Militaria, South African Journal of Military Studies, Vol 45,

No. 1, 2017, pp. 90-121.

doi : 10.5787/45-1-1194.

Creative Commons License-CC BY-NC-ND 4.0 of South Africa. The Defence Act of 1912 stipulated that members of the Union Defence Force (UDF) could render defence in protection of the Union of South Africa. ${ }^{2}$ Botha's parliamentary motion for the 
invasion of GSWA was passed on 10 September 1914, 91 votes to ten. ${ }^{3}$

The commandos formed a large part of the UDF. They were independent in thought and impatient of any formal means of control. The commandos were astute, and they relied on their tactical sense and their rifle as a means of offence. ${ }^{4}$ The development of the horse and the rifle in conjunction is part of the commando tradition. The result of this system was a soldier who could deliver accurate and economical fire and who could cross almost any kind of terrain. ${ }^{5}$ It is possible that certain military characteristics of the commandos were well suited for the execution of manoeuvre warfare.

Manoeuvre warfare theory is a military theory that proposes the defeat rather than the complete destruction of the enemy through attrition. ${ }^{6}$ This theory contrasts from the belief in superiority in numbers, which is of fundamental importance to the attrition theorist. David Killingray argues that numerical superiority was a crucial aspect in the defeat of the Germans in GSWA. ${ }^{7}$ Byron Farwell is of the opinion that the Germans were outmatched given the disparity in numbers. ${ }^{8}$ Thomas Ungleich describes the campaign in the most recent pro-German account and argues that the South African numerical superiority was the main cause of victory. ${ }^{9}$ Jan Smuts junior, the son of General Smuts, writes that in the campaign in GSWA, "the victory was due to superior tactics as well as overwhelming strength". ${ }^{10}$

Brigadier General JJ Collyer puts the strength of the UDF at 50000 compared to the modest 7000 German soldiers whom Gerald L'ange estimates at a more humble 2000 German soldiers with 4000 reservists and 480 policemen capable of rendering military service. ${ }^{11}$ Collyer writes about the military advantages enjoyed by the Germans over the South Africans, which included an undivided command, a conventionally trained homogeneous force, superior artillery and good logistics, which included a well-structured rail system. ${ }^{12}$ Deneys Reitz identified similar advantages, but also included the difficult terrain, which made the provision of logistics extremely difficult for the UDF. ${ }^{13}$

At a superficial glance, the numerical difference in the size of the forces could lead to the misperception that the campaign was relatively easy for the UDF. This was not necessarily the case. Each UDF advance would take the logistical system to breaking point and would require an operational pause to recuperate.

This article reports on an analysis of manoeuvre warfare theory in the 1914 South African campaign in GSWA to determine whether the cause of victory could be attributed to the superiority in numbers of the UDF or rather to the application of operational concepts congruent to manoeuvre warfare theory. 
The German defeat was analysed through using applicable parts of the theories of EA Cohen and J Gooch ${ }^{14}$ as well as that of MI Handel. ${ }^{15}$ These authors explored the cause of defeat relative to organisational factors as well as tangible and intangible aspects, which influence the outcome of battles and campaigns.

Gooch and Cohen created a methodology for defeat, which requires one to determine the cause of the military failure (from the German perspective), which is followed by determining the critical lapses or tasks that were left undone and which led to the defeat. The third step was to do a layered analysis, which included some of the organisational aspects which led to failure. ${ }^{16}$ This analysis was used by Ian van der Waag in his seminal piece on the Battle of Sandfontein, ${ }^{17}$ and the present study thus built on the central tenets of his thesis.

Handel identifies a formula to determine total military power (refer to Figure 1). This equation was used in the analysis of the campaign in GSWA when comparing the UDF and the German force. The quantitative elements are the numbers of soldiers and equipment. 'Materiel quality' refers to whether the equipment used by a given military was of a good standard and 'non-materiel quality' refers to the intangibles of military forces, such as morale, motivation, level of training, doctrine, staff work and organisation. ${ }^{18}$

\section{Total military power $=$ quantity $\mathbf{x}$ materiel quality $\mathbf{x}$ non-materiel quality}

Figure 1. Formula for total military power. ${ }^{19}$

\section{Manoeuvre warfare theory}

Manoeuvre theory comprises the basic idea of defeating your enemy through the least amount of effort and with attaining the least loss possible. ${ }^{20}$ Manoeuvre is regarded by many as the most important way of achieving victory in conflict. ${ }^{21}$ Attrition and manoeuvre theories are prominent basic - yet opposite - military theories applied to conventional warfare. Both theories have the same aim, which is to attain victory in war, however they differ in method. The manoeuvre theory framework, which was applied in the present study, is derived largely from the works of Robert Leonhard, William Lind and Richard Simpkin. ${ }^{22}$ Manoeuvre warfare identifies three possible methods for attaining victory: pre-emption, dislocation and disruption. 


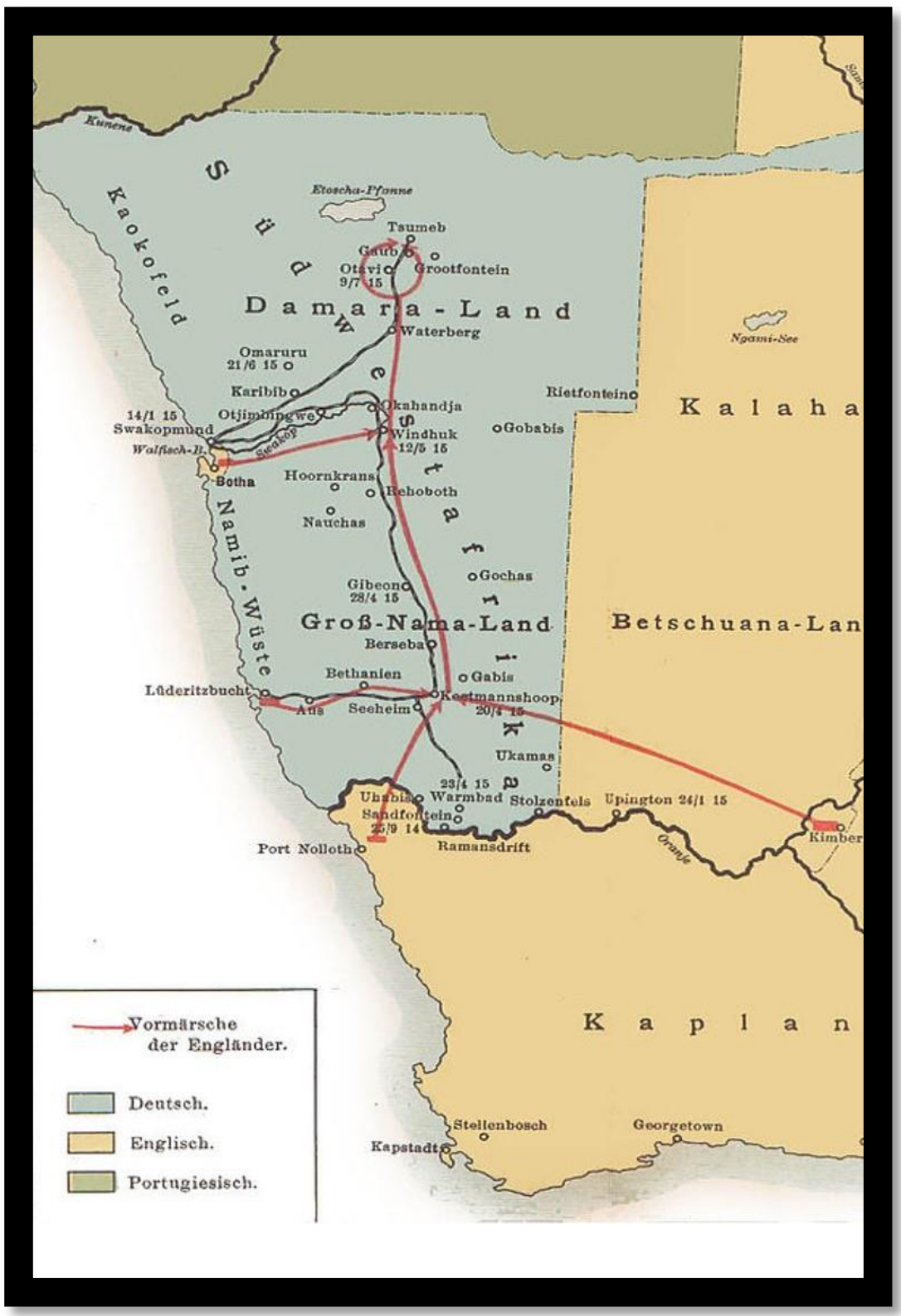

Map 1: German South West Africa c. 1915.23 
Pre-emption relies on movement over firepower and surprise as well as a rapid decision-making cycle. ${ }^{24}$ Simpkin argues that pre-emption makes use of manoeuvre to prevent the outbreak of combat. ${ }^{25}$ Further, pre-emption attacks the enemy's plan in such a way that it denies the enemy freedom of action. In doing so, the initiative is taken from the enemy. ${ }^{26}$ Pre-emption is based on intuition more than intelligence. $^{27}$

Dislocation involves the removal of the enemy's combat strength from the decisive point. This includes avoiding combat where the enemy is stronger and choosing how to position one's forces so as to ensure the best results. ${ }^{28}$ Dislocation is based on good intelligence and makes use of surprise, deep penetrating advances and envelopment so as to dislocate the physical and psychological spheres of the enemy. ${ }^{29}$

Disruption involves the destruction of assets of the enemy fighting capability, which paralyses the enemy force. ${ }^{30}$ This comprises the third means of achieving victory through manoeuvre warfare, and involves defeating the enemy by attacking their centre of gravity. ${ }^{31}$

On the opposite side of the spectrum is attrition theory which, in contrast to manoeuvre theory, emphasises the breaking of the opponent's will by destruction through the massing of forces and direct attack. Manoeuvre warfare, on the other hand, emphasises avoiding the "enemy's strength in favour of attacking his weakness". 32

Attrition theory focuses on the tactical level, and the central purpose is to bring the opposing force to a decisive battle through the concentration of forces. The use of superior firepower and technology is directly related to the employment of attrition theory. ${ }^{33}$ This theory is Clausewitzian by nature to the extent that it places the emphasis on the idea of the central battle.

Manoeuvre warfare is linked to a rapid decision-making cycle, lower-level command initiative and a decentralised command system. Lind discusses the aspect of decentralisation of military forces, and comments that the decision-making cycle of a given military force must be done at a pace that is faster than that of the enemy and that this must be done by the respective decentralised forces. ${ }^{34} \mathrm{~A}$ rapid decisionmaking cycle relates to the pre-emption and dislocation of the enemy.

Sun Tzu's famous quote is rephrased by Leonhard who claims, "the highest and purest application of manoeuvre theory is to pre-empt the enemy, disarm or neutralise him before the fight". ${ }^{35}$ Tzu phrases this as, "supreme excellence is not to fight and conquer in all your battles but rather in breaking the enemy's resistance without fighting", 36 
Manoeuvre theory is essentially offensive in nature; however, it may occur that a defensive position may be taken to await supplies. ${ }^{37}$ Logistics is fundamental to warfare and determines the size of the force which can be deployed, how these forces are to be maintained in terms of rations, ammunition, fuel and other requirements. It further determines the flow and rhythm of operations. ${ }^{38}$ An operational pause must be taken at a time when the operation is no longer sustainable. Such pause along one line of operations should be met with the hastening of the tempo on another line of operations. ${ }^{39}$

\section{The levels of war, decision-making cycles and manoeuvre}

As a theory, manoeuvre warfare is flexible and extends itself over the strategic, operational and tactical levels of war. ${ }^{40}$ At tactical level, manoeuvre and attrition theories are interwoven where manoeuvre is translated into mobility and attrition into firepower. ${ }^{41}$ Furthermore, at tactical level, firepower provides the stability which manoeuvre in the form of mobility cannot provide. ${ }^{42}$

The levels of war are intrinsically related to their respective centres of gravity. Clausewitz defines the centre of gravity as "the hub of all power and movement on which everything depends". ${ }^{43}$ Manoeuvre warfare theory adapted the conceptual understanding of the term 'centre of gravity' to refer to the critical vulnerability which, if compromised, would lead to the paralysis of the enemy and not just a reduction of the enemy's military capabilities. ${ }^{44}$ Through attacking the enemy's centre of gravity, one should defeat the enemy. The centre of gravity can be at the strategic, operational and tactical levels of war. At each level, the centres of gravity of war are related to the objective of that specific level. ${ }^{45}$

Colonel John Boyd's decision cycle represents the continuous process of observation, orientation, decision and action (OODA), and is thus referred to as the OODA loop. ${ }^{46}$ By completing this cycle before the enemy and disrupting the enemy's OODA cycle, a given force gains the initiative. Boyd's theory is largely psychological and deals with the will and morale of the fighting force. ${ }^{47}$ Only a decentralised military force allows for a fast OODA cycle. ${ }^{48}$ The commander's intent forms the decision-making framework for the subordinate commanders whether at operational or tactical level. ${ }^{49}$ Some theorists maintain that command decisions have to be made at the tactical level for manoeuvre theory to be effective. ${ }^{50}$

Sun Tzu refers to the military components necessary to execute manoeuvre warfare, which include "an 'ordinary' force that would pin the enemy and an 'extraordinary' force that would perform a manoeuvre to outflank the enemy". ${ }^{51}$ The ordinary force fixes the enemy and the extraordinary force strikes. ${ }^{52}$ Jomini states 
that the chances of victory are far increased when there is a direct attack and a flanking manoeuvre. ${ }^{53}$

\section{Overview of the German South West African campaign}

The German forces adopted a defensive strategy and their commander at the time, Colonel Joachim von Heydebreck, made maximum use of the geography of GSWA as well as internal lines of communication to delay the UDF invasion and prevent their redeployment to other theatres of the Great War. ${ }^{54}$ Von Heydebreck was succeeded by Major Victor Franke who was subsequently promoted to the rank of lieutenant colonel.

The Germans had at their disposal an advanced railway system for mobility and the natural obstacles of the desert and a lack of water resources so as to obstruct the invading force. ${ }^{55}$ Botha described GSWA as "a natural fortress". ${ }^{56}$ The Germans placed the railway system strategically to transport troops from the coast to inland positions at a rapid pace. Furthermore, the railway system took into account the military consideration of massing troops at a rapid rate against the Ovambos in the north or against the Union in the south. ${ }^{57}$

The Germans had the advantage of operating on interior lines, which enabled them to concentrate superior numbers within most of the colony during the advance of the South African forces. ${ }^{58}$ Despite having superior military numbers, the UDF was not able to advance with their entire force at any one time on the respective lines of operations.

Over half of the UDF was comprised of highly mobile mounted soldiers and the other half was made up of infantry. The campaign also made use of aircraft for forward reconnaissance. ${ }^{59}$ Mobility was the key requirement for the planned movements of the campaign. The Union raised 33308 mounted troops for the Afrikaner Rebellion and the GSWA campaign and 15397 non-mounted troops. ${ }^{60}$

The initial strategic plan for the invasion of GSWA included amphibious landings at Lüderitz and Walvis Bay. The force at Walvis Bay was to advance via the shortest distance to Windhoek. The strategic plan, as determined by Smuts, was stifled by the British War Office who determined that the naval vessels could only transport South African troops to Lüderitz. The invasion plan was thus changed and improvised to a less efficient one with which Smuts was not entirely satisfied. ${ }^{61}$

The restructured invasion plan comprised the amphibious landings of the South African forces at Lüderitz and at Port Nolloth. The military force at Port Nolloth landed on 31 August 1914 and advanced across the Orange River into 
GSWA via Raman's Drift and Sandfontein. The amphibious landing at Lüderitz took place on 18 September 1914 and the port city was taken unopposed. Raman's Drift was occupied on 14 September 1914. The wireless station at Swakopmund was also destroyed on 14 September 1914 by naval shelling. ${ }^{62}$ The first invasion resulted in the Battle of Sandfontein and the first operational loss for the UDF.

Diasram No 2.

Showing the stratigic relation of S.W. Africas to the Union of South Africa

The shaded deticd portions represent

Desert or semidesert coumbiry.

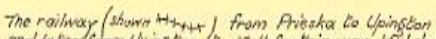

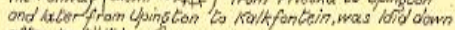
ofter hostiliciez commenced.

Cape Town was the point of strategie Concentration for the deplopment on Swakup - Walfith Bay and Luderitz Bay. Upingtion and Steintop were for the Southern Foress and kiruman was the concentration point for the Eastern Forse.
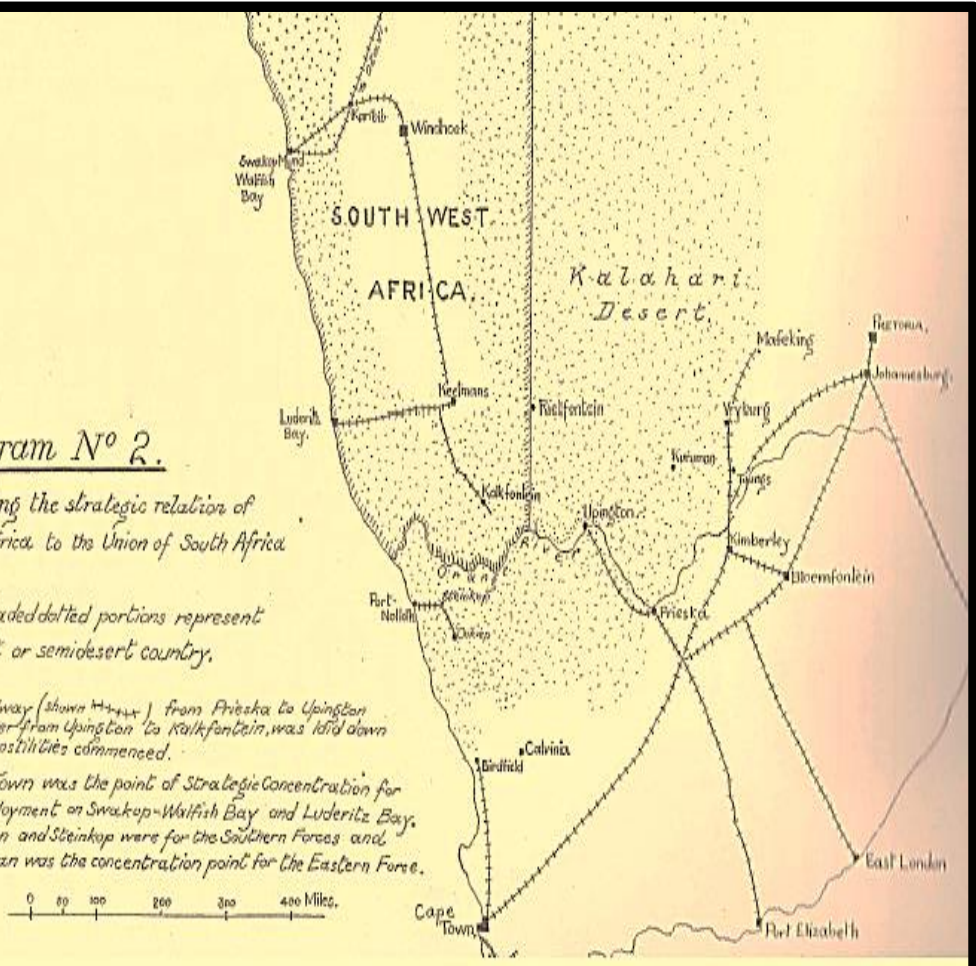

Map 2. Terrain and infrastructure of GSWA. ${ }^{63}$ 
The second invasion effort involved the amphibious landings of South African forces at Walvis Bay (Northern Army) and the reinforcing of the forces at Lüderitz (Central Force, see Graph 1). The second invasion plan was similar to the original plan envisioned by Smuts. The second amphibious landing was executed, and Walvis Bay was taken unopposed on 25 December 1914. There were also two South African force groupings (Eastern and Southern Forces) deployed from across the Union and GSWA border in March 1915. Once the UDF had been deployed, a great obstacle to the campaign was that of the physical geography of GSWA, which influenced the logistical supply of the troops.

Botha was in personal command of the northern operations, which comprised a two-prong easterly advance from Walvis Bay to Windhoek. The southern operations involved a north-easterly drive from the forces at Lüderitz and a northerly advance from the forces advancing through Namaqualand and the Kalahari Desert. The British war effort required control of the harbours and wireless stations in GSWA, which were referred to as "a great and urgent imperial service". ${ }^{4}$

\section{The battle of Sandfontein, 26 September 1914}

The Union's initial invasion of GSWA comprised two force groupings. Colonel (later Major General) Henry Lukin landed in Port Nolloth on 31 August 1914 along with an artillery complement, five mounted regiments, the Witwatersrand Rifles, a section of engineers and an ammunition column. ${ }^{65}$ Lukin's advance with 'A' force, the first of the Force groupings, was hindered by 'B' Force commander, Commandant Manie Maritz, who had defected (as he did not identify with British interests) and was from then on in collusion with the Germans. ${ }^{66}$

Maritz was supposed to have supported Lukin in the cross-border advance. Collyer contends that even if everything had gone according to plan, the advance would have been risky but an advance of either force in isolation was akin to failure ${ }^{67}$ Botha would later testify in the Rebellion Inquiry that, in terms of time and space, it was understood that Maritz would not have been able to have supported Lukin. ${ }^{68}$ This theme requires further investigation.

The Germans knew that the South Africans had to advance along predetermined routes as the availability of water dictated. ${ }^{69}$ There was a German force advancing on Ramans Drift from the north whilst Lukin advanced on Ramans Drift from Steinkopf in the south. Lukin wanted to occupy the position before the arrival of the Germans. ${ }^{70}$ Lukin's planned advance was to go through Ramans Drift, Warmbad, Kalkfontein and Seeheim. ${ }^{71}$ The main force of Lukin arrived at Ramansdrift on 24 September $1914 .^{72}$ 


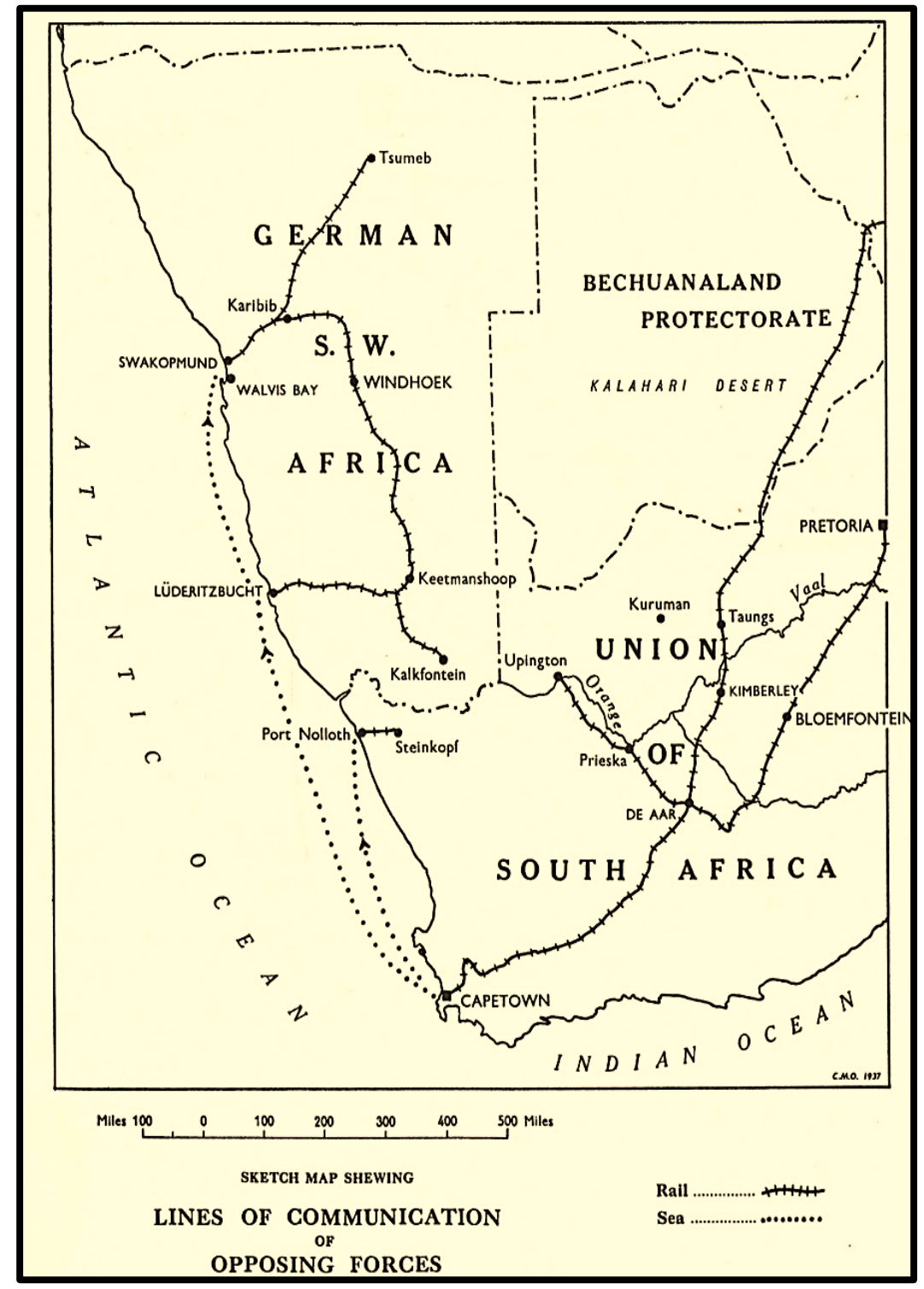

Map 3: Lines of communication. ${ }^{73}$ 
Lukin was reluctant to send his forces north of the Orange River without having the necessary supply lines in place. However, he was ordered by Defence Headquarters to advance and he thus sent Lieutenant Colonel RC Grant to move up to Sandfontein, which had the only water source en route to Warmbad. Defence Headquarters subsequently ordered supplies up to Sandfontein to facilitate the advance on Warmbad. ${ }^{74}$ By requesting Lukin to advance from the south, Defence Headquarters planned to take pressure off the force that had landed at Lüderitz. ${ }^{75}$

Von Heydebreck was in command of the Schutztruppe in GSWA until his death in November 1914. He was well regarded as a competent commander with vast military experience and initiative. On the morning of 26 September 1914, the Germans converged on Sandfontein with four columns, which had been massed in secret on the unsuspecting South Africans. The Germans attacked from the north, south, east and west. ${ }^{76}$ The Germans started with an artillery bombardment, which commenced a little after Grant's arrival at $07: 25 .{ }^{77}$ Grant deployed his artillery at the base of the hill and the infantrymen formed a defensive line around the hill using rifle fire to keep the Germans at bay. The Germans bombarded the South African position extensively shelling their wagons, horses and mules as well as spraying shrapnel over the infantrymen. ${ }^{78}$ The German infantry and machine-gun sections surrounded the South African camp and bombarded the UDF from the northwest, northeast and southwest. ${ }^{79}$

The Germans intensified their bombardment of Sandfontein and after ten hours of fighting, Grant raised the white flag. He realised that no military objective could be reached by further resistance as they were cut off, and the relief force had not managed to repel the Germans or spring them free. On inspecting the battlefield on 27 September 1914, Lukin was in agreement with Grant's decision to surrender. ${ }^{80}$

Many sources attribute the defeat at Sandfontein to the treachery of Maritz, as he did not advance to support the cross-border operations of Lukin. ${ }^{81}$ Collyer assigns a great deal of the blame to Defence Headquarters, which demanded the advance of Lukin's force. Collyer raises the point that, regardless of whether Maritz supported Lukin or not, the Germans could have massed greater forces than the combined strength of Maritz and Lukin's forces. ${ }^{82}$ Warwick places most of the blame on Smuts for the haste with which the Union advanced and for the placement of political objectives before the military considerations and realities. ${ }^{83}$ Van der Waag reevaluates the loss at Sandfontein looking at the battle from a strategic and organisational point of view bringing in a balanced approach to the complex study of military victories and defeats. ${ }^{84}$ 


\section{Analysis of the Battle of Sandfontein with reference to manoeuvre warfare theory}

From a South African perspective, the Battle of Sandfontein demonstrated an example of static warfare, which is more inclined to attrition than manoeuvre warfare theory. The UDF column advanced to Sandfontein, which was an untenable defensive position, where they had to rely exclusively on firepower in response to the German attack.

The Germans made excellent use of mobility. The German forces were operating on internal lines of communication whereas the South Africans were operating on external lines of communication. The German forces were numerically superior at the Battle of Sandfontein as they mobilised approximately 2000 soldiers from different parts of GSWA while the South African forces numbered approximately $300 .{ }^{85}$

The speed of the German advance robbed the Union of its military initiative and they were essentially reactive to a completely dominant German attack. The operation was characterised by inefficient South African intelligence and predictable military advances ${ }^{86}$ Lukin justified his capture of Sandfontein in that he wanted to hold the only water supply in the area. ${ }^{87}$

The Union's advance had reached its culmination point at Sandfontein. The advance of Lukin's entire force was extended from Sandfontein to Raman's Drift, Houm's Drift, Steinkopf and Port Nolloth. ${ }^{88}$ The Union force was advancing to no definable military operational objective while extending its logistical lines. Lukin was not able to support the forces deployed at Sandfontein effectively. ${ }^{89}$ At the tactical level, the water supply was an objective; however, it did not link up to an operational objective. Tactical objectives should link up to an operational objective. An advance on any given tactical and operational objectives should have sufficient logistics to keep the troops supplied and mobile.

At strategic level, the Union required an advance into GSWA to show solidarity to the British war effort and the urgent imperial service. At operational level, there was no conceptualisation of a definable decisive point or objective, which theoretically should have led to the German centre of gravity. The operational advance was thus directed by a strategic consideration without realistic operational objectives and without sufficient logistical support.

Following the initial invasion of GSWA and defeat at Sandfontein, the UDF was recalled to quell the internal threat of rebellion within the Union. After the Battle of Sandfontein and the Rebellion, the UDF was united under a unified leadership 
structure. The subsequent invasion of GSWA followed four axes of advance, which resembled the initial strategic concept envisioned by Smuts. ${ }^{90}$

\section{The northern offensive}

The Union forces took Walvis Bay on 25 December 1914 without a shot fired in anger, and Swakopmund followed in January 1915. Colonel PCB Skinner led the initial invasion of Walvis Bay, which was unopposed by the Germans excepting for sporadic skirmishing and some booby traps left behind. ${ }^{91}$ Botha, as Prime Minister of the Union, was appointed as Commander-in-Chief of the expeditionary force by special commission in terms of Section 81 of the Defence Act of $1912 .^{92}$

The main thrust of the UDF strategy was to take place in the north of GSWA. The advance of the Northern Army was directed at Windhoek and at the Schutztruppe headquarters. The most fundamental consideration in the northern advance was the availability of water. Botha could only move from water point to water point. The defensive line of Riet, Pforte and Jakkalsfontein was the first major tactical objective and was coincidentally a water source. Ritchie argues "Botha's principle task was to take an army right across the Namib Desert and to do that he had to capture every water-hole and keep it." 93

On 19 March 1915, Botha moved from Husab and then proceeded with staged operations to take the Riet defensive line. ${ }^{94}$ The $1^{\text {st }}$ and $2^{\text {nd }}$ Mounted Brigades were used for the attack. Husab was at a position which ran parallel to the Swakop River. The German position at Riet, Pforte and Jakkalsfontein extended for 48 kilometres and was strongly defended with 2000 troops and four artillery pieces. ${ }^{95}$ The Langer Heindrich hills formed a natural defensive structure on the eastern bank of the Swakop River and were held by the Germans. ${ }^{96}$ Furthermore, the Germans occupied the Husabberg, Pforteberg and Geisberg hills north of the river. ${ }^{97}$ In response to the German's strong defensive position, Botha stated, "I shall out manoeuvre them with flank movements." 98

Botha wanted to engage and outflank the forces at Riet, Pforte and Jakkalsfontein simultaneously to prevent the German forces from reinforcing a particular front. ${ }^{99}$ In the early hours of the morning of 20 March, Brits's scouts made contact with the German positions. The initial contact was followed by the South African artillery engaging the Germans. ${ }^{100}$ Botha was unable to envelop the German forces directly at Riet. ${ }^{101}$ Botha deployed Alberts to envelop the German force at Pforte, which was positioned to the northwest of Riet, and formed part of the German defensive line. 


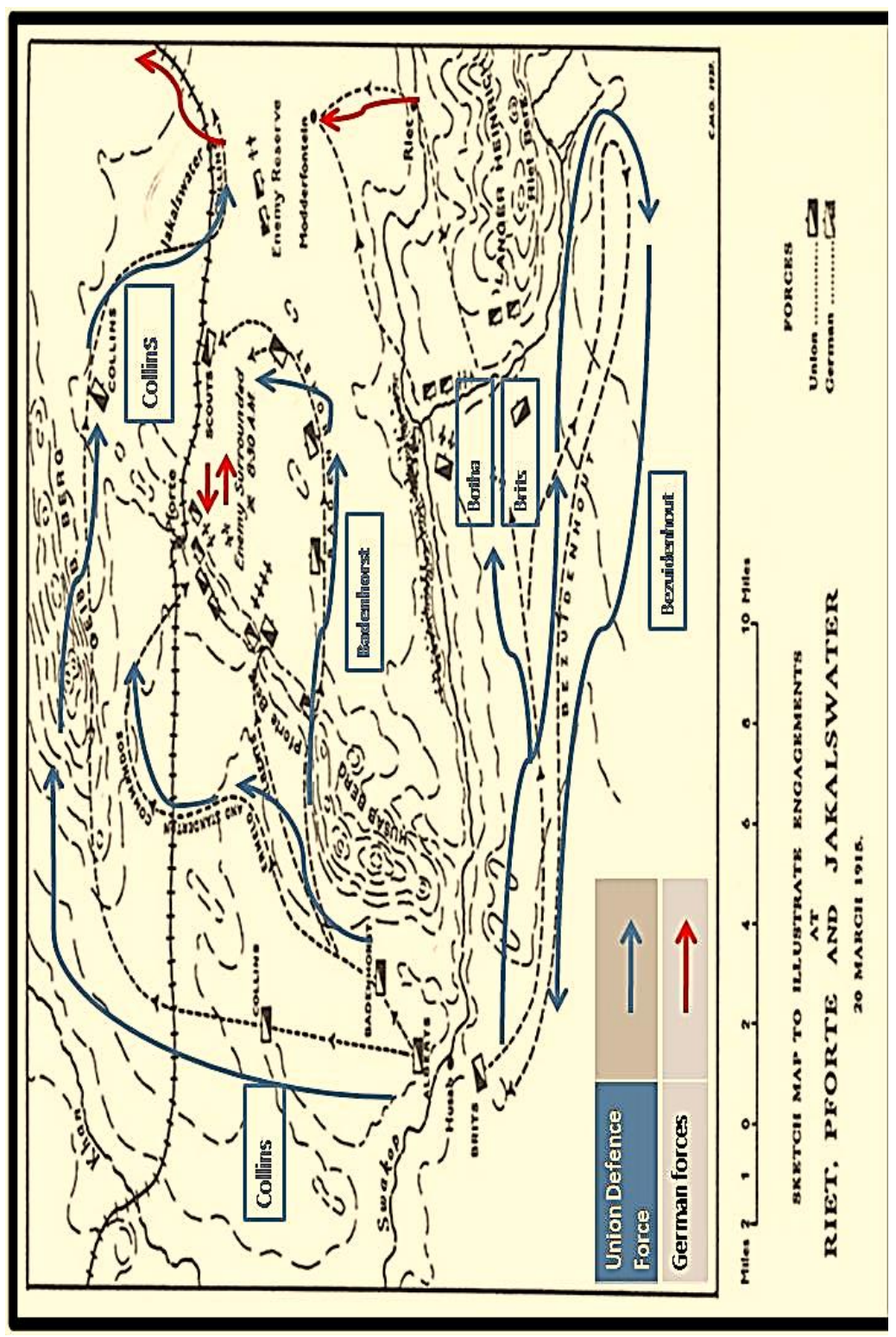

Map 4. The Battle of Riet, Pforte, Jakalswater. ${ }^{102}$ 
Alberts sent the Standerton and Ermelo commandos to engage the Germans directly at Pforte, and Swarts's scouts and two other commando groupings were sent through the gap between Husabberg and Pforteberg who hurried through the corridor under German artillery fire. The movement was done in spectacular fashion and enabled the railway between Pforte and Jakkalswater to be cut, which isolated the forward German detachments. ${ }^{103}$ Alberts captured the whole force with all their equipment at Pforteberg. ${ }^{104}$ The German forces captured totalled 209 soldiers and two guns. ${ }^{105}$ The swiftness of the commandos ensured the successful capturing of the position. ${ }^{106}$

Commandant Collins's men pursued the Germans at Jakkalsfontein. However, the strong and direct German artillery fire on the commandos caused them to withdraw, leaving 43 soldiers as prisoners of war. ${ }^{107}$ The total UDF loss was $13 \mathrm{dead}, 41$ wounded and 43 prisoners of war while the Germans reported 16 dead, 21 wounded and 264 prisoners of war. ${ }^{108}$

\section{The southern offensive}

General D McKenzie took over command of the central force at Lüderitz from Colonel PS Beves in October 1914. Beves was deployed with the $1^{\text {st }}$ Transvaal Scottish Regiment, Imperial Light Horse and seven guns from the $7^{\text {th }}$ Citizen Force Battery. ${ }^{109}$ The forces in the south were opposed by Major Ritter who had a battery of artillery and four mounted regiments, as well as Maritz with approximately 800 rebels. ${ }^{110}$ The strength of McKenzie's force on 22 December 1914 was 2183 mounted men and 5754 non-mounted men. ${ }^{111}$

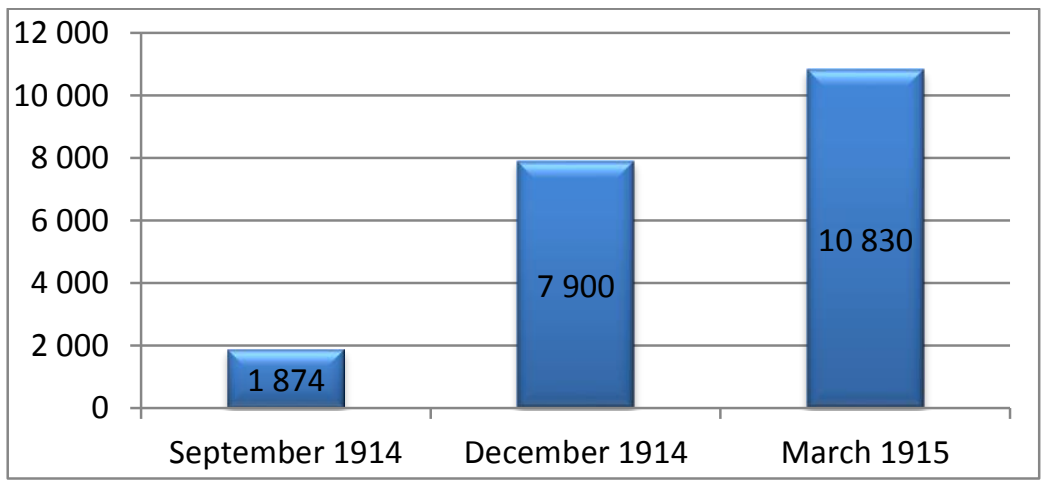

Graph 1. Central Force increase in troops (including the forces in the field and 1815 soldiers en route in March 1915). ${ }^{112}$ 


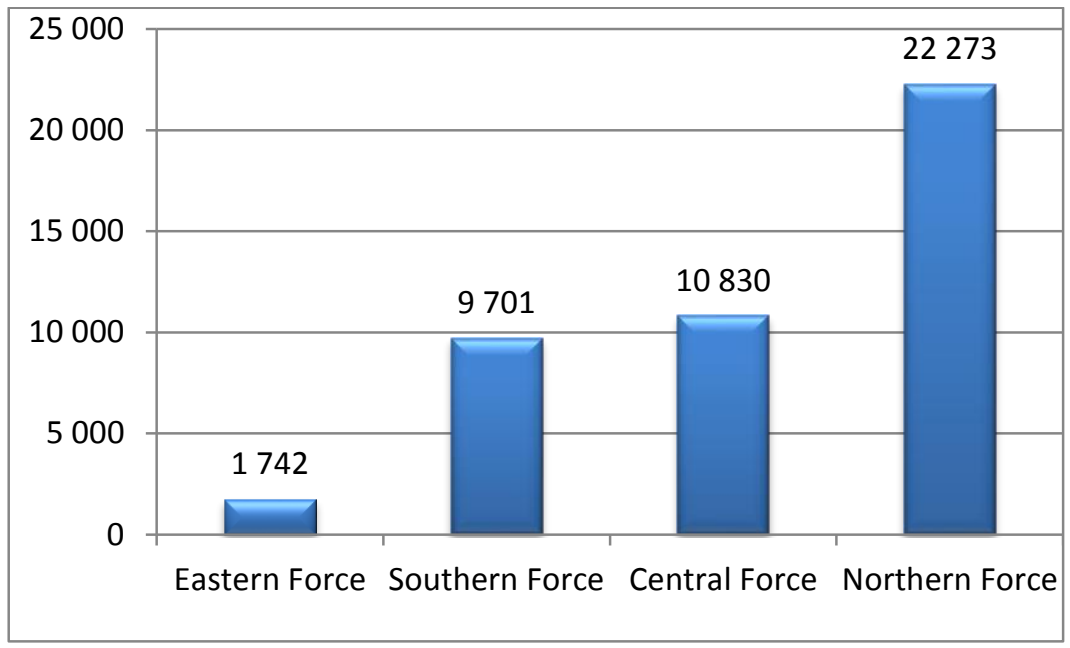

Graph 2. Strength of the Southern Army (Central, Southern and Eastern Forces) by March 1915 (inclusive of the forces in the field and 5895 soldiers en route). ${ }^{113}$

Van Deventer's force had a numerical strength of 6958 on 4 April 1915 of whom 6176 were mounted. ${ }^{114}$ This allowed him to cover large distances at a fast rate. Van Deventer took Kalkfontein on 5 April 1915. The Germans deployed in a strong position in the Karas Mountains outside Kalkfontein. Van Deventer executed a double envelopment, which induced the Germans to retreat. After a brief fight, the Germans withdrew to Keetmanshoop. ${ }^{115}$

The Germans eventually evacuated Aus on their own accord. The rapid advance of Berrange and Van Deventer from the east and south (across Namaqualand and the Kalahari) respectively dissuaded the Germans from maintaining their defensive position at Aus. ${ }^{116}$ Aus was evacuated due to strategic pressure within GSWA. ${ }^{117}$

Dane is of the opinion that the Germans were outmanoeuvred in the south of GSWA. ${ }^{118}$ Graph 2 shows the numerical strength of the South African forces. On 14 April 1915, the mounted soldiers of Berrange and Van Deventer totalled $7506 .{ }^{119}$

The southern offensive advanced on Gibeon following the capture of Aus. Collyer states that the German withdrawal from Gibeon was not related to the actions of the UDF but it was rather the result of the overall strategic situation and the Union's advance in the north of GSWA. ${ }^{120}$ 


\section{The advance on Windhoek}

The Union forces were in dire need of logistics. The rapid movements and forced marches led to problems in keeping the forward troops supplied. ${ }^{121}$ Collyer argues that keeping the mounted soldiers mobile was the most important consideration as the advance on Windhoek depended on their mobility. ${ }^{122}$ Botha stated that his chief obstacle in the campaign was the lack of transport. ${ }^{123}$

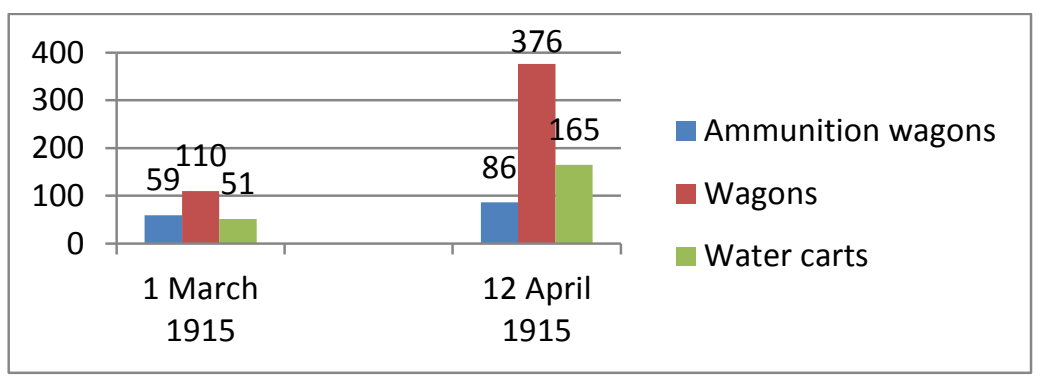

Graph 3. Increase in UDF logistical support. ${ }^{124}$

Botha appealed to parliament to make funds available for mules and wagons. This was finally approved by the end of April. Botha thus had sufficient stores to provide his commandos five days of sustainment in the field. Parliament approved 300 wagons and mules for the drive to Windhoek. ${ }^{125}$ The strength of the mounted unit showed an increase from 59 ammunition wagons, 110 wagons and 51 water carts on 1 March 1915 to 86 ammunition wagons, 376 wagons and 165 water carts on 12 April 1915. ${ }^{126}$

The $1^{\text {st }}$ Mounted Brigade under the command of Brits was sent to Kubas, the $2^{\text {nd }}$ Mounted Brigade under the leadership of Alberts was deployed to Potmine and Otjimbingwe, and Colonel JS Wylie was sent with the infantry up the railway via Sphinx to Kubas. ${ }^{127}$ The movements of the commandos were designed for Brits to engage the German forces south of Karibib whereas Myburgh would commit to a large sweeping envelopment between Karibib and Okahandja. ${ }^{128}$

Karibib was taken without much resistance, and Windhoek officially surrendered to Botha on 12 May 1915. This included the capture of the wireless station, which the Germans had dissembled on their own initiative. ${ }^{129}$ The Germans retreated from Windhoek to Tsumeb, the location of their last wireless station. For six weeks from mid-May until mid-June, Botha prepared his forces and logistics for the final advance. ${ }^{130}$ 


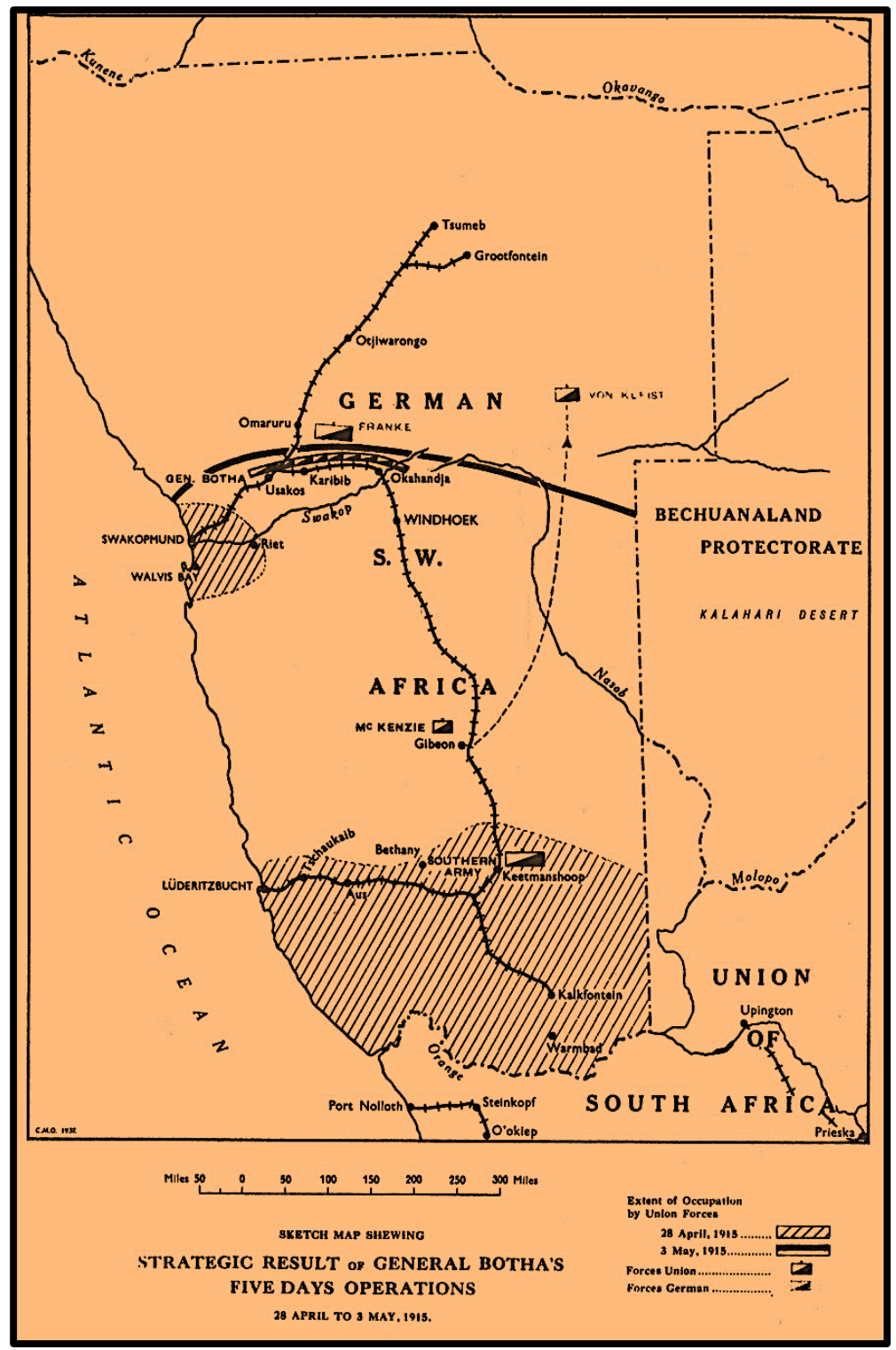

Map 5. Result of the South African actions up to 3 May 1915. ${ }^{131}$ 


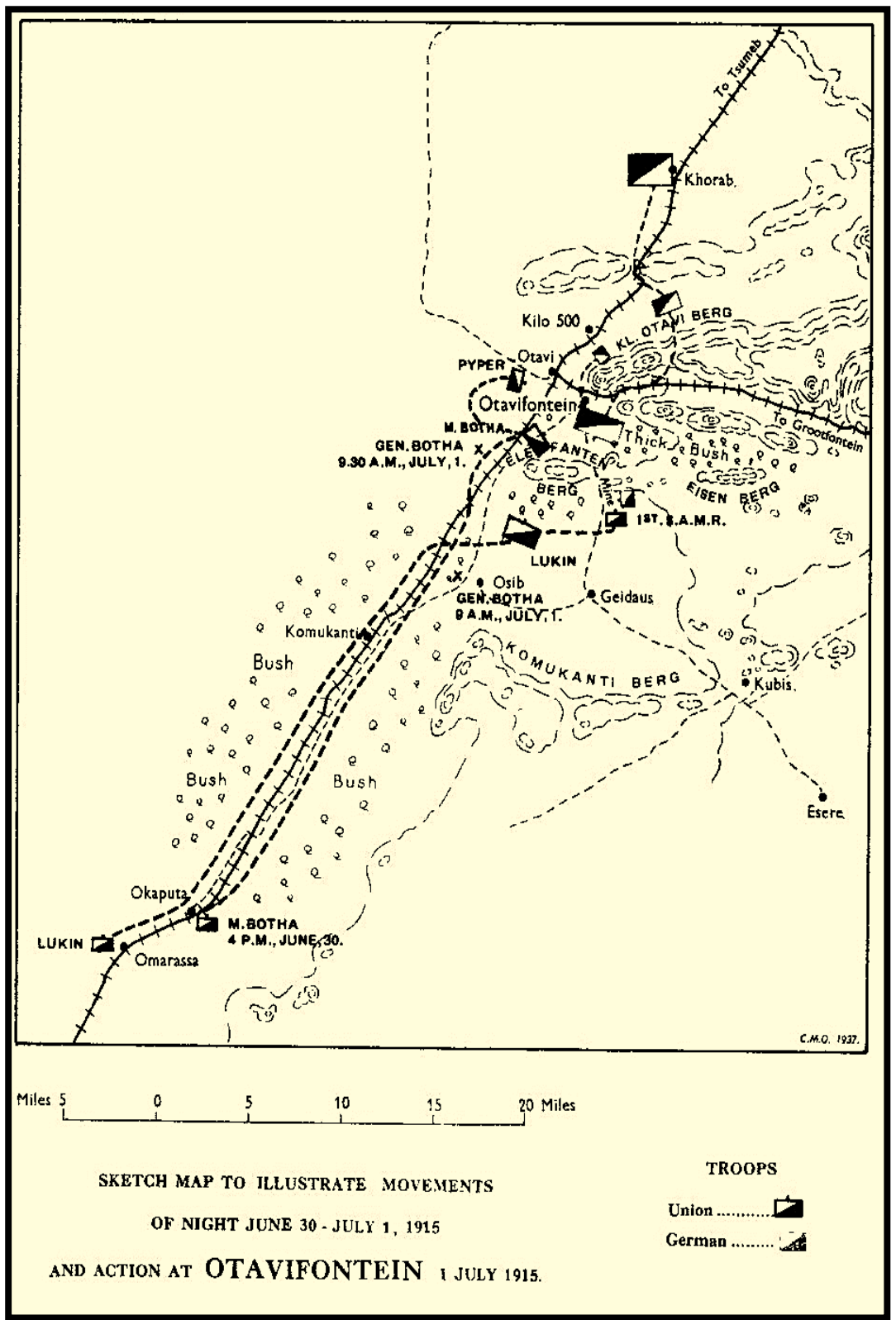

Map 6: Action at Otavifontein. ${ }^{132}$ 


\section{The final envelopment}

The advance started on 18 June 1915. ${ }^{133}$ Earlier in the campaign, Collyer had become a temporary colonel and was given the appointment of assistant adjutant general (chief-of-staff). ${ }^{134}$ As chief-of-staff, Collyer did well to organise the watering of the columns as they marched. He had the water and its capacity tested on the routes of advance. He planned the advance in a staggered fashion that allowed for the different sections of the advancing columns to be watered sequentially. ${ }^{135}$ The UDF was reasonably well supplied (by commando standards), which allowed for the full use of their mobility. ${ }^{136}$

Brits took Omaruru on 19 June 1915. ${ }^{137}$ The advance moved from Omaruru to Kalkveld where it was thought that the Germans were planning to put up a stand. The Germans did not fight but withdrew northwards. Botha's force then advanced to Otjiwarongo. ${ }^{138}$ Myburgh deployed from Wilhelmstal in a wide envelopment to take Grootfontein. Botha understood the probability that he would lose contact with Myburgh. ${ }^{139}$ The UDF was advancing over a front of 95 kilometres. ${ }^{140}$ Botha allowed Myburgh out on his own initiative as he trusted the instincts of Myburgh who in turn understood the intent of the commander-in-chief. ${ }^{141}$

Manie Botha advanced towards the German position at Otavifontein while Lukin was deployed to the east of the Elefantenberg to stop a possible flank attack by the Germans. ${ }^{142}$ The Germans had 3372 rifles with 36 guns and 22 machine guns at Otavifontein, which were not effectively employed against the Union's $5^{\text {th }}$ and $6^{\text {th }}$ Mounted Brigades. ${ }^{143}$ The Germans executed a fighting withdrawal to Grootfontein. ${ }^{144}$ Manie Botha pushed forward through bushy and rugged terrain, which forced the German commander to withdraw. The German chief-of-staff stated that, had they had one hour more to prepare, the Germans would have destroyed the Union forces. ${ }^{145}$ Manie Botha ensured surprise by rushing the German position. ${ }^{146}$ Whittal gives the figures as 10 Germans killed and 25 wounded and seven South African wounded and four dead in the action. ${ }^{147}$

Myburgh departed on 18 June, and moved via Okasisse and Wilhelmstal, arriving at the Waterberg plateau on 26 June. On 29 June Myburgh moved to Otajewita and then to Omboamgomde. On 2 July 1915, he arrived at Esere. During the extensive marching, the troops and horses were without water for up to two days. ${ }^{148}$

The South Africans received intelligence that the Germans were entrenched at Gaub and the right wing of the $3^{\text {rd }}$ Brigade was tasked to envelop the enemy's rear to the west, while the $2^{\text {nd }}$ Brigade was sent to the enemy's rear to the east. ${ }^{149}$ 
Myburgh defeated the small German force at Gaub on 2 July, and subsequently advanced on Tsumeb. ${ }^{150}$ The Germans in Tsumeb surrendered on 6 July 1915. ${ }^{151}$

The Germans at Namutoni surrendered to Brits on 8 July. ${ }^{152}$ In order to achieve this feat Brits had to undertake an extensive and arduous march. Brits departed on 18 June from Karibib while Myburgh departed from Okasisse. Brits moved to Etanaho, Omatjenne and Otijasu where his troops eventually found potable water. Brits's men took Ombika on 3 July and Okakuejo on 4 July, and on 5 July Rietfontein was taken. Brits's brigade covered 563 kilometres in 13 days in the march to Namutoni. The German force at Namutoni subsequently surrendered. ${ }^{153}$

Ritchie contends, "Franke was surrounded before he knew it. So neat and swift had been the plan of the Commander-in-Chief that the Germans was incredulous until his scouts kept coming in and telling him what the real state of affairs was." 154 The Germans were facing Botha and the infantry at Otavifontein and Myburgh and Brits had cut the German retreat. The final offensive against the last German position was made by 5250 mounted soldiers and 4750 riflemen with 32 artillery weapons against approximately 5000 German soldiers in well-defended positions with artillery and machine guns. ${ }^{155}$

On 9 July 1915, the Germans accepted Botha's offer for unconditional surrender. ${ }^{156}$ The German forces at Khorab included approximately 4000 troops and 30 guns. ${ }^{157}$ Seitz sent a letter to confirm the German surrender at 02:00 on 9 July. ${ }^{158}$ The GSWA campaign was the first successful campaign by a dominion of the British Empire during the First World War.

\section{Analysis of the final envelopment of the German forces with regard to manoeuvre warfare theory}

The reasons for defeat and victory are complex and they are by their nature inextricably intertwined. In order for one to determine the cause of victory, it is also equally important to understand the reason for the defeat of a given military force. As mentioned, Gooch and Cohen have created a taxonomy for defeat in which the first step is to determine the cause of the military failure or defeat. This step is followed by determining the critical tasks, which led to the defeat, and the third step is to do a layered analysis of the organisational aspects, which led to the failure. ${ }^{159}$

The cause of defeat for the Germans was not that they were outnumbered, but rather that they did not put up a defensive battle. The German force surrendered with their entire fighting force intact. The Germans surrendered with 4740 soldiers, 37 artillery pieces and 22 machine guns and substantial amounts of ammunition, 
which had been stockpiled. ${ }^{160}$ The German and Union forces never engaged in a sustained pitched battle at tactical level at the end of the campaign.

Several critical tasks were left incomplete by the German forces during the final envelopments. The German forces could have, and with hindsight should have, offered battle at Kalkveld and at Otavifontein. The German position at Kalkveld was vacated by the German forces without offering battle.

According to Botha, the German forces at Kalkveld withdrew because they feared that they would be surrounded by the UDF. Botha alluded to the fact that the terrain and the circumstances did not allow for an encirclement of the German position at Kalkveld. ${ }^{161}$ The position at Otavifontein was critical to the UDF's route of advance as it held an important water source. Botha mentioned that, if the UDF had not been able to have captured Otavifontein, the Union forces would have been compelled to retreat and regroup. ${ }^{162}$

Franke had opted for a defensive strategy where he had conserved his forces to give battle at the critical time and place. ${ }^{163}$ Franke had written a letter to his forces, which was of an antagonistic tone and spoke of an imminent colossal clash between the German and Union forces. Botha stated that, despite the aggressive tone of Franke's letter and the fact that physically the German force was largely intact, it was evident that the German morale was shaken. ${ }^{164}$ The German retreat from Otavifontein was a clear indication that their morale had collapsed. ${ }^{165}$

Gooch and Handel state that once the critical failures have been analysed they should be compared to the different levels of organisation. The German failure to give battle at the required times at Otavifontein and Kalkveld was the result of the shaken morale of the German subordinate commanders. The German force was never previously engaged in the type of campaign which they encountered.

The Union force's mobility was something novel and the Germans found themselves retreating on a continuous basis. The German military were not familiar with facing a rapid, highly mobile enemy, which targeted their logistical and communication lines. The Germans were at this stage accustomed to trade space for time, and retreat became an operational procedure. The constant withdrawal of the German forces resulted in the forces becoming more and more disconnected to the prospect of an actual pitched defensive battle. The leadership of Franke and his subordinate commanders in this regard must be questioned. Furthermore, it should be questioned whether the German force was more acquainted, familiar and comfortable with offensive warfare as opposed to a defensive campaign. ${ }^{166}$ Captain HO Von Kleist and Ritter were perhaps overwhelmed by the magnitude of their commands and their responsibilities in the final phase of the campaign. 
The Germans appear to have accepted defeat long before the final surrender to the UDF. The tacit understanding of German sections and detachments to retreat may have become an organisational norm, which led to the final surrender. Figure 1 represents the equation that was applied to the German and Union forces in the analysis of the final envelopment in GSWA. In terms of the formula, the number of the Union forces was considerably higher than that of the German forces. The materiel quality of the equipment of the German and Union forces was approximately equal. As the campaign progressed, the UDF controlled the railway, which allowed for the logistical provisioning of the Union forces. The non-materiel quality, which refers to morale, motivation, offensive spirit and leadership, was higher for the UDF than for the German force.

The results of the formula show that the Union forces were stronger than the German forces in numbers, materiel quality (with the control of the railway) and non-materiel quality. On the point of numerical superiority, the Union did not have overwhelmingly stronger numbers than the Germans during the final envelopments. Botha stated that the knowledge of the location of the enemy forces made it feasible to take the required number of troops and no more. ${ }^{167}$

During the last phase of the campaign and the UDF's final envelopments, the Germans were on interior lines. The German force was in the central position and they were able to concentrate superior forces on any of the separate Union forces that were deployed in a forward position. ${ }^{168}$ Hence, the numerical superiority of the Union's forces was not the most decisive factor during the final envelopments.

What was significant about the South African campaign in GSWA was the brevity of the campaign. Handel states that qualitative factors are usually the most decisive factors in a short war. ${ }^{169}$ In this case, this refers to the offensive spirit leadership and morale of the UDF. Handel also claims that quantitative superiority normally becomes important in extended campaigns. ${ }^{170}$ The briefness of the campaign in GSWA is thus testament to the strength of the qualitative factors of the UDF. The importance of numerical superiority is in no way undermined; however, the cause of victory for the South Africans and the cause of defeat for the Germans were not direct results of numerical strength. Had the Germans repulsed the Union forces during the final envelopments, the length of the campaign would have become protracted. In that case, it would be understandable that the UDF's superior numbers would eventually have influenced the termination of the campaign.

Seitz in official correspondence with the Kaiser stated that the German defeat was caused by the superior numbers of the UDF, which had encircled them at Khorab by taking the surrounding German positions at Namutoni and Tsumeb. Seitz further claimed that every attempt to break through the Union encirclement was futile. ${ }^{171}$ 
Botha gave the reason for the Union victory as the effect of surprise on the German force, which was caused by the rapidity of the enveloping attacks on the German positions at Tsumeb and Namutoni. ${ }^{172}$ The collapse of the German force's morale was central to the loss. The numerical superiority of the Union was an important factor but can be regarded as a simple explanation to the complex phenomenon of military failure and defeat.

The significance of the campaign is related to its brevity. This article links the briefness of the campaign to the qualitative factors of the UDF, which in turn was analysed with manoeuvre warfare theory. The final envelopments resulted in the dislocation of the physical and psychological dimensions of the German commanders. The low morale and lack of offensive spirit and cohesion of the German force resulted in their surrender without having been physically harmed. The surrendering of a military force without physical resistance indicates that they were compelled to do so by psychological pressure and the perceived threat of death or destruction.

\begin{tabular}{|l|l|l|l|c|c|}
\hline & & From & To & $\begin{array}{c}\text { Distance } \\
(\mathrm{km})\end{array}$ & $\begin{array}{c}\text { Time } \\
(\text { hours })\end{array}$ \\
\hline $\begin{array}{l}\text { Northern } \\
\text { Army }\end{array}$ & $\begin{array}{l}\text { Left wing } 2^{\text {nd }} \\
\text { Mounted } \\
\text { Brigade }\end{array}$ & Husab & $\begin{array}{l}\text { Jakkalswater } \\
\text { (and back) }\end{array}$ & 122 & 22 \\
\hline $\begin{array}{l}\text { Northern } \\
\text { Army }\end{array}$ & $\begin{array}{l}5^{\text {th }} \text { Mounted } \\
\text { Brigade }\end{array}$ & Okaputa & Kilo 500 & 70 & 18 \\
\hline $\begin{array}{l}\text { Northern } \\
\text { Army }\end{array}$ & $\begin{array}{l}6^{\text {th }} \text { Mounted } \\
\text { Brigade }\end{array}$ & Omarassa & Elefantsnek & 58 & 15 \\
\hline $\begin{array}{l}\text { Northern } \\
\text { Army }\end{array}$ & $\begin{array}{l}3^{\text {rd }} \text { and } 5^{\text {th }} \\
\text { Mounted } \\
\text { Brigades }\end{array}$ & Riet & Otjimbingue & 112 & 37 \\
\hline $\begin{array}{l}\text { Central } \\
\text { Force }\end{array}$ & $\begin{array}{l}7^{\text {th }}, 8^{\text {th }} \text { and } 9^{\text {th }} \\
\text { Mounted } \\
\text { Brigades }\end{array}$ & Berseba & Gibeon & 112 & 72 \\
\hline $\begin{array}{l}\text { Southern } \\
\text { Force }\end{array}$ & $\begin{array}{l}\text { Van } \\
\text { Deventer's } \\
\text { column }\end{array}$ & Neu Khais & Kabus & & \\
\hline
\end{tabular}

Table 1. Best forced marches. ${ }^{173}$

\section{Analysis of the German South West African campaign and manoeuvre warfare theory}

The campaign in GSWA was characterised by swift advances followed by operational pauses, which were used to consolidate the space covered. The South African forces in the north paused from 20 March until the end of April 1915 so as to get the necessary supplies. During the operational pause in the north, the offensive 
in the south continued. Kalkfontein and Gibeon were taken in April 1915. This demonstrates operations on different lines of advance. The UDF was in the field for 133 days and they were on the move for 24 days. ${ }^{174}$ The 24 days in which the forces were executing operational movements was accompanied by 109 days of operational pause. The German military centre of gravity in GSWA was not the capital but their military command and operational headquarters. A specific operational or strategic headquarters is a typical centre of gravity. ${ }^{175}$ Leonhard argues, "operational planners must determine how to use the available combat power to achieve the goals of a campaign". ${ }^{176}$ Botha made efficient use of the commandos and mounted infantry with their high mobility and the infantry with their ability to take and hold ground. The extraordinary and ordinary forces, as mentioned by Sun Tzu, indicate a highly mobile force to execute envelopments and an ordinary force to take and hold ground. ${ }^{177}$ Botha understood the importance of mobility and surprise as the most important considerations on the tactical and strategic level. ${ }^{178}$ Botha's emphasis on mobility was vividly demonstrated by the UDF return in strength in December 1914 indicating 33308 mounted soldiers. ${ }^{179}$

\section{Conclusion}

Liddel Hart argues that the psychological and physical dislocation of the enemy on a continuous basis requires the advancing force to change its lines of operations through divergent advances on a central objective or through divergent advances on successive decisive points on route to the centre of gravity. ${ }^{180}$ This was the case in GSWA where the UDF had a northern and southern offensive, which were directed at the German operational headquarters as the centre of gravity.

Manoeuvre theory holds that mobility is more important than firepower. ${ }^{181}$ Certain elements of the opposing force have to be destroyed following which the eventual positioning of forces will induce defeat with the threat of annihilation. ${ }^{182}$ The numerical superiority of the UDF facilitated the taking and holding of ground. The lines of communication were secured by the infantry who manned the blockhouses. The number of commandos allowed the Union forces to pursue different lines of advance; therefore, the importance of numbers cannot be underestimated. However, the deciding factor in the operational and strategic success points towards manoeuvre theory and Botha's innate understanding of its attributes.

The mobility of the commandos ensured tactical and operational surprise resulting in quick, decisive outcomes. Reflecting on Botha's military background, Whittal argues, "his elastic military training allowed for the accomplishment of the campaign". ${ }^{183}$ The operation was designed as a quick, decisive campaign of 
manoeuvre. ${ }^{184}$ The campaign in GSWA provides an ideal case study for manoeuvre warfare theory.

\section{Endnotes}

1 The author is currently a visiting scholar at New York University, Centre on International Cooperation and the article is adapted from his MA thesis. See forthcoming book publication 'The First Campaign Victory of the Great War', Helion Publishers, 2019. antoniogarcia81@yahoo.com; ag6304@ nyu.edu

2 WA Dorning. "A concise history of the South African Defence Force 1912-1987”. Militaria 17/22. 1987. 4.

${ }^{3} \mathrm{H}$ Strachan (ed). The Oxford illustrated history of the First World War. Oxford: Oxford University Press, 1998, 546; L'ange gives the final votes as 92 to 12 in favour of Botha: G L'ange. Urgent imperial service. Rivonia: Ashanti, 1991, 17.

${ }^{4}$ L'ange $o p$. cit. p. 11 . For the latest study relating to Union Defence Force doctrine see, D Katz "A clash of military doctrine: Brigadier-General Wilfrid Malleson and the South Africans at Salaita Hill, February 1916", Historia. 62/1.2017.

5 Anon. Union of South Africa and the Great War, 1914-1918: Official history. Pretoria: Government Printers, 1924, 38.

${ }^{6}$ R Leonhard. The art of maneuver. New York, NY: Ballantine, 1994. 19.

${ }^{7}$ D Killingray. "The war in Africa". In Strachan (ed) op. cit. p. 93.

${ }^{8}$ B Farwell. The Great War in Africa 1914-1918. New York, NY: Norton, 1986, 75.

9 TR Ungleich. "The defence of German South West Africa during World War I". MA thesis. University of Miami, 1974, 52.

10 JC Smuts. Jan Christian Smuts. London: Cassell, 1952, 259.

${ }^{11}$ L'ange op. cit. p. 158.

12 JJ Collyer. The campaign in German South West Africa, 1914-1915. Pretoria: Government Printers, 1937, 21.

${ }^{13}$ DE Reitz. Trekking on. London: Travel Book Club, 1947, 69.

${ }^{14}$ EA Cohen \& J Gooch. Military misfortunes: The anatomy of failure in war. New York, NY: The Free Press, 1990.

${ }^{15}$ MI Handel. War strategy and intelligence. London: Frank Cass, 1989.

${ }^{16}$ Cohen \& Gooch op. cit., p. 46.

${ }^{17}$ I van der Waag. "The Battle of Sandfontein, 26 September 1914: South African Military reform and the German South-West Africa Campaign, 1914-1915". First World War Studies 4/2. 2013. 3.

${ }^{18}$ Ibid., p. 96.

${ }^{19}$ Handel op. cit., pp. 95-96.

${ }^{20}$ Leonhard op. cit., p 4.

${ }^{21}$ BT Soleberg. "Maneuver warfare: Consequences for tactics and organisation of the Norwegian Infantry". MMAS thesis. United States Army Command and Staff College, 2000, 21. 
${ }^{22}$ Leonhard op. cit.; S Lind. Manoeuvre warfare handbook. London: Westview Press, 1985; RE Simpkin. Race to the swift. London: Brassey's Defence Publishers, 1986.

${ }^{23}$ Map of the South-West Africa Campaign in 1915: E Rothert. Karten und Skizzen zum Weltkrieg. Düsseldorf: A. Bagel, 1916. Originally uploaded to Wikipedia by Victor_falk on 31 July 2007.

$<$ https://en.wikipedia.org/wiki/South-

West_Africa_campaign\#/media/File:S\%C3\%BCdwestafrika_1915.jpg> Open source map accessed 24 February 2017.

${ }^{24}$ Leonhard op. cit., pp. 63-64.

${ }^{25}$ Simpkin op. cit., p. 140.

${ }^{26}$ British Army. Operations. British Army Doctrine. Andover: Army Publications, 2010, 5-16.

${ }^{27}$ South African Army College. Operational concepts: Staff officer's operational manual Part VII. Pretoria: 1 Military Printing Regiment, 1996, 7/5-6.

${ }^{28}$ Leonhard op. cit., pp. 67-68; South African Army College op. cit., pp. 7/5-10.

${ }^{29}$ British Army op. cit., pp. 5-16; South African Army College op. cit. pp. 7/5-6.

${ }^{30}$ South African Army College op. cit., pp. 7/5-6; British Army op. cit., pp. 5-17.

${ }^{31}$ Leonhard op. cit., p. 73.

32 Ibid., p. 14.

${ }^{33}$ A Esterhuyse. "The theories of attrition versus manoeuvre and the levels of war". Strategic Review for Southern Africa 22/2. 2001. 86.

${ }^{34}$ Lind op. cit., p. 6.

${ }^{35}$ Leonhard op. cit., p. 19.

${ }^{36}$ S Tzu. tr. L Giles. The art of war. ebook \#132. May 1994. <http://www.gutenberg.org/files/132/txt> Accessed on 23 January 2012, 5.

${ }^{37}$ Soleberg op. cit., p. 21.

${ }^{38} \mathrm{R}$ Holmes (ed). The Oxford companion to military history. Oxford: Oxford University Press, 2003, 513.

${ }^{39}$ South African Army College op. cit., pp. 7/12-1.

${ }^{40}$ Soleberg op. cit., p. 5.

${ }^{41}$ Esterhuyse op. cit., p. 91.

42 Simkin op. cit., p. 23.

${ }^{43}$ Soleberg op. cit., p. 26.

${ }^{44}$ Leonhard op. cit., p. 44.

${ }^{45}$ South African Army College op. cit., p. 7/11-2.

${ }^{46}$ Leonhard op. cit., p. 51.

${ }^{47}$ Soleberg op. cit., p. 38.

${ }^{48}$ Lind op. cit., p. 6.

${ }^{49}$ South African Army College op. cit., pp. 7/11-2, 7/1-2.

${ }^{50}$ Esterhuyse op. cit., p. 93.

${ }^{51}$ Leonhard op. cit., p. 31.

${ }^{52}$ C Grant \& J Gooch (ed). "The use of history in the development of contemporary doctrine". Paper presented at the conference sponsored by the Director of Development and Doctrine, Larkhill, 26 March 1996, 13. 
${ }^{53}$ AH Jomini, AH. trs. Mendell, GH and Craighill, WP. The art of war. Rockville: Art Manor, 2007, 149.

${ }^{54}$ Van der Waag op. cit., p. 3.

${ }^{55}$ For the latest study on the role of water in the GSWA campaign see, E. Kleynhans, "A Critical Analysis of the Impact of Water on the South African Campaign in German South West Africa, 1914 1915", Historia. 61/ 2. 2016.

${ }^{56}$ WK Hancock \& J van der Poel (ed). Selections from the Smuts papers. Volume III. (London: Cambridge University Press, 1966, 255.

${ }^{57}$ E Dane, E. British campaigns in Africa and the Pacific 1914-1918. London: Hodder and Stoughton, 1919, 27, 28.

58 Anon. op. cit., pp. 12-13; HF Trew. Botha treks. London: Blackie, 1936, 94.

${ }^{59}$ B Nasson. Springboks on the Somme. Johannesburg: Penguin, 2007, pp 63-65.

${ }^{60}$ DOD Archives. Adjutant General 1914-1921 (hereafter AG 1914-1921). Box 150. AG 1914/1921. Summarised states of forces and garrisons. List of all Union Defence Force members on active duty.

${ }^{61}$ Van der Waag op. cit., p. 7.

${ }^{62}$ Nasson op. cit., p. 67.

${ }^{63}$ Department of Defence Archives (hereafter DOD Archives). Secretary for Defence (hereafter called SD). Box 252. 17138 IO General Botha's Despatch (GOC MC GSW Campaign), 9 July - 28 October 1920. Historical record of the campaign in German South West Africa. 4 November 1919.

${ }^{64}$ Collyer op. cit., p. 6.

${ }^{65} \mathrm{H}$ Paterson. "First allied victory: The South African campaign in German SouthWest Africa, 1914-1915". Military History Journal 13/2. 2004. 1.

${ }^{66}$ Nasson op. cit., pp. 43-44; RC Warwick. "The role and legacy of Major General Sir Henry Timson Lukin”, Scientia Militaria South African Journal of Military Studies 34/2. 2006. 74.

${ }^{67}$ Collyer op. cit., p. 29.

${ }^{68}$ DOD Archives. Diverse Group 1. Box 2. Rebellion Commission of Enquiry

Volume 1, Testimony by

General Louis Botha, June 1916.

${ }^{69}$ Ibid., p. 23.

${ }^{70}$ L'ange op. cit., p. 21.

${ }^{71}$ Collyer op. cit., p. 31.

${ }^{72}$ Farwell op. cit., p. 78.

${ }^{73}$ Ibid., opposite p. 24.

${ }^{74}$ Collyer op. cit., p. 32.

${ }^{75}$ DOD Archives. SD. Box 252. 17138 Reports of Force Commanders in German South West Africa. Telegraph from General Staff to General Lukin. 23

September 1914; Anon. op. cit., p. 14; Simpkins op. cit., p. 17.

${ }^{76}$ L'ange op. cit., p. 28.

${ }^{77}$ Farwell op. cit., p. 78.

${ }^{78}$ L'ange op. cit., pp. 30-32.

${ }^{79}$ Collyer op. cit., p. 41. 
${ }^{80}$ DOD Archives. SD. Box 252. 17138 Reports of Force Commanders in German South West Africa. Operations in and around Sandfontein $25^{\text {th }}, 26^{\text {th }}$ and $27^{\text {th }}$ September 1914. 19 August 1915.

${ }^{81}$ Nasson op. cit., p. 67; Dane op. cit., p. 35; J Meintjes. General Louis Botha. London: Cassell, 1970, 233; Paterson op. cit., p. 2.

${ }^{82}$ Collyer op. cit., p. 47.

${ }^{83}$ Warwick op. cit., p. 65.

${ }^{84}$ Van der Waag op. cit.

${ }^{85}$ Ibid., p. 11.

${ }^{86}$ Ibid., p. 8.

${ }^{87}$ DOD Archives. SD. Box 252. 17138 Reports of Force Commanders in German South West Africa. Operations in and around Sandfontein $25^{\text {th }}, 26^{\text {th }}$ and $27^{\text {th }}$ September 1914. 19 August 1915.

${ }^{88}$ Van der Waag op. cit., p. 10.

${ }^{89}$ DOD Archives. SD. Box 252. 17138 Reports of Force Commanders in German South West Africa. Operations in and around Sandfontein $25^{\text {th }}, 26^{\text {th }}$ and $27^{\text {th }}$ September 1914. 19 August 1915.

${ }^{90}$ Van der Waag op. cit., p. 15.

${ }^{91}$ L'ange op. cit., pp. 138-139.

92 DOD Archives. AG 1914 - 1921. Box 8. G5/305/9199 Commander-and-chief. Government notice for the next issue of the Union Gazette. 18 October 1914.

${ }^{93}$ ME Ritchie. With Botha in the field. London: Longmans, 1915, 33.

${ }^{94}$ Nasson op. cit., p. 70.

95 Meintjes op. cit., p. 261.

${ }^{96}$ Paterson op. cit., p. 5.

${ }^{97}$ L'ange op. cit., p. 181.

${ }^{98}$ Hancock \& Van der Poel op. cit., p. 243.

${ }^{99}$ HFB Walker. A doctor's diary in Damaraland. London: Edward Arnold, 1917, 42.

100 Trew op. cit., pp. 97-102; Ritchie op. cit., pp. 34-35.

${ }^{101}$ L'ange op. cit., p. 184.

${ }^{102}$ Base image for the map was taken from Collyer: Collyer op. cit., p. 65. The base image was then modified to represent the Battle of Riet, Pforte, Jakkalsfontein.

103 Ibid., p. 186.

104 Trew op. cit., p. 114.

105 Paterson op. cit., p. 5.

106 Collyer op. cit., p. 70.

${ }^{107}$ Collyer op. cit., p. 72.

${ }^{108}$ L'ange op. cit., p. 188.

${ }^{109}$ Ibid., p. 94.

${ }^{110}$ Collyer op. cit., p. 80.

${ }^{111}$ DOD Archives. AG 1914-1921. Box 150. AG 1914/1921. Summarised states of forces and garrisons. Central Force. 22 December 1914.

112 Bar graph compiled from: Van der Waag op. cit., p. 9; DOD Archives. AG 1914/1921. Summarised states of forces and garrisons. Central Force. 22 
December 1914; DOD Archives, AG 1914/1921. Summarised states of forces and garrisons. Central Force. 24 March 1915.

${ }^{113}$ Bar graph compiled from DOD Archives. AG 1914/1921. Summarised states of forces and garrisons. Central Force. 24 March 1915.

${ }^{114}$ DOD Archives. AG 1914-1921. Box 150. AG 1914/1921. Summarised states of forces and garrisons. General summary. 4 April 1915.

115 L'ange op. cit., pp. 151-154.

116 Ibid., p. 209.

117 Anon. op. cit., p. 47.

${ }^{118}$ Dane op. cit., p. 56.

${ }^{119}$ DOD Archives. AG 1914-1921. Box 150. AG 1914/1921. Summarised states of forces and garrisons. General summary. 14 April 1915.

${ }^{120}$ Collyer op. cit., p. 92.

121 Trew op. cit., p. 125.

122 Collyer op. cit., p. 52.

${ }^{123}$ Hancock \& Van der Poel op. cit., p. 247.

${ }^{124}$ DOD Archives. AG 1914-1921. Box 182. Weekly strength returns of various units. Mounted Strengths field state. 12 April 1915.

${ }^{125}$ L'ange op. cit., p. 244.

${ }^{126}$ DOD Archives. AG 1914-1921. Box 182. Weekly strength returns of various units. Mounted Strengths field state. 12 April 1915.

${ }^{127}$ L'ange op. cit., p. 247.

${ }^{128}$ Collyer op. cit., p. 100.

${ }^{129}$ Nasson op. cit., p. 74; Anon. op. cit., p. 40; Meintjes op. cit., p. 264; W Whittal. With Botha and Smuts in Africa. London: Cassell, 1917, 62; Paterson op. cit., p. 6.

130 Anon. op. cit., p. 32.

${ }^{131}$ Collyer op. cit., opposite p. 105.

132 Collyer op. cit., opposite p. 137.

133 Meintjes op. cit., p. 267.

${ }^{134}$ DOD Archives. AG 1914-1921. Box 8. G305/9199. Commander-in-Chief and staff. Government notice for the next issue of the Union Gazette. 18 October 1914.

135 Trew op. cit., p. 154.

${ }^{136}$ Collyer op. cit., p. 125.

${ }^{137}$ Ritchie op. cit., p. 55.

138 Trew op. cit., p. 188.

${ }^{139}$ Collyer op. cit., p. 133.

140 Trew op. cit., p. 153.

${ }^{141}$ DOD Archives. SD. Box 252. 17138 Reports of Force Commanders in German South West Africa. Despatch number 4 by General Botha covering the period 15 th May to $18^{\text {th }}$ July 1915; L'ange op. cit., p. 290.

142 Ritchie op. cit., p. 59.

${ }^{143}$ Collyer op. cit., p. 141.

${ }^{144}$ L'ange op. cit., p. 296.

${ }^{145}$ Collyer op. cit., p. 140; Anon. op. cit., p. 47. 


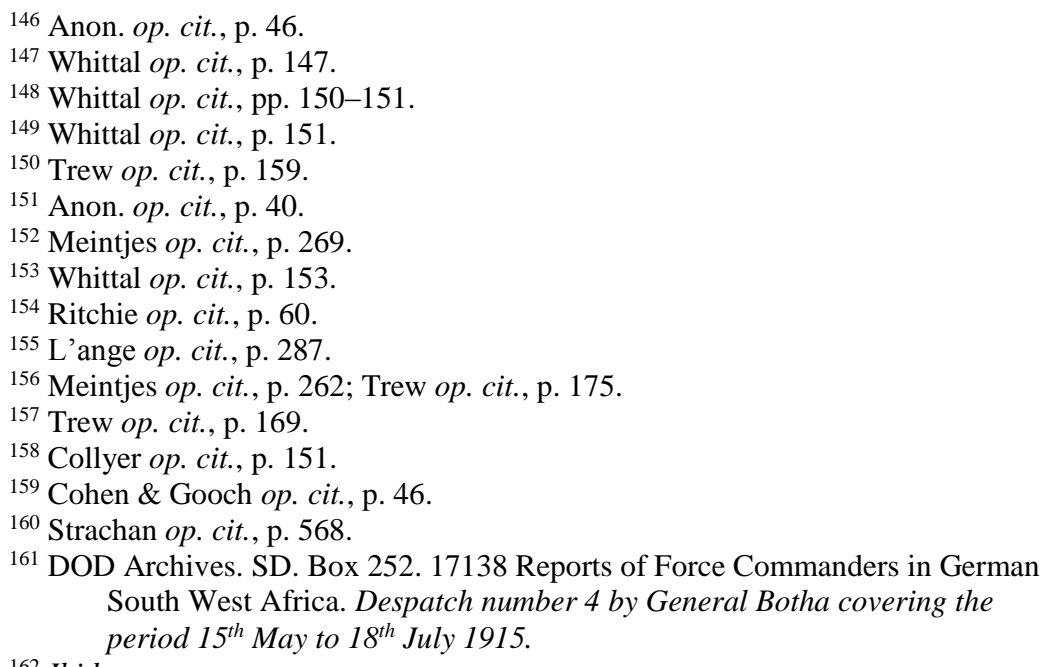

162 Ibid.

${ }^{163}$ DOD Archives. SD. Box 252. 17138 Reports of Force Commanders in German South West Africa. Translation of an appeal by Lieutenant Colonel Franke, Commander-in-Chief of the Protectorate. 28 June 1915.

${ }^{164}$ DOD Archives. SD. Box 252. 17138 Reports of Force Commanders in German South West Africa. Despatch number 4 by General Botha covering the period 15 th May to $18^{\text {th }}$ July 1915; A Garcia. "Manoeuvre warfare in the South African Campaign in German South West Africa during the First World War". MA thesis. University of South Africa, 2015, 112.

165 Strachan op. cit., p. 568.

166 The German victories at the Battle of Sandfontein, the Battle of Naulila (against the Portuguese military) and the Herero and Namaqua campaigns (massacres/genocide) are examples of previous German military victories which comprised offensive operations.

${ }^{167}$ DOD Archives. SD. Box 252. 17138 Reports of Force Commanders in German South West Africa. Despatch number 4 by General Botha covering the 168 Ibid. period $15^{\text {th }}$ May to $18^{\text {th }}$ July 1915.

${ }^{169}$ Handel op. cit., p. 96.

${ }^{170}$ Ibid., p. 96.

${ }^{171}$ DOD Archives. SD. Box 886. Letter of Dr Seitz to the Kaiser. 4 August 1915.

172 DOD Archives. World War 1 German South West Africa. Box 23a. Citations German South West Africa. Northern Army, Commander of the $1^{\text {st }}$ Mounted Brigade Special Appointments. 17 February 1918; Garcia op. cit., p. 115.

173 DOD Archives. SD. Box 252. 17138 IO General Botha's Despatch (GOC MC GSW Campaign) 9 July to 28 October 1920. Historical Record of the Campaign in German South West Africa. 4 November 1919.

${ }^{174}$ Collyer op. cit., p. 158. 
175 South African Army College op. cit., p. 7/11-8.

${ }^{176}$ Leonhard op. cit., p. 10.

177 Soleberg op. cit., p. 32.

${ }^{178}$ Collyer op. cit., p. 173.

${ }^{179}$ DOD Archives. AG 1914-1921. Box 150. AG 1914/1921. Summarised states of forces and garrisons. Mounted Brigade Strength. 22 December 1914; Garcia op. cit., p. 115.

${ }^{180}$ Soleberg op. cit., p. 30.

181 Esterhuyse op. cit., p. 91.

182 Ibid., p. 132.

183 Whittal op. cit., p. 4.

${ }^{184}$ Dane op. cit., p. 32. 